\title{
Підготовка висококваліфікованих спринтерів з вадами зору в умовах середньогір'я
}

\section{Лейля Аджаметова}

Харківська державна академія фізичної культури, Харків, Україна

\begin{abstract}
Мета: визначити вплив тренувань в умовах середньогір'я на гостроту зору та рівень спеціальної підготовленості висококваліфікованих легкоатлетів з порушеннями зору, які спеціалізуються у спринтерському бігу.

Матеріал і методи: дослідження проводилося в умовах середньогір'я за участю Заслуженого майстра спорту України з легкої атлетики серед спортсменів з вадами зору. Були використані наступні методи: аналіз і узагальнення науково-методичної літератури, аналіз документальних матеріалів (щоденники та плани підготовки), педагогічне спостереження, педагогічний експеримент (авто експеримент), візометрія, методи математичної статистики.

Результати: тренування в умовах середньогір'я призвели до позитивних змін показників функціонального стану зорового аналізатора та рівня спеціальної підготовленості спортсменки, що брала участь у дослідженні.

Висновки: застосування в підготовці висококваліфікованої спринтерки з вадами зору тренувань в умовах середньогір'я позитивно вплинуло на рівень спеціальної підготовленості та на гостроту зору.
\end{abstract}

Ключові слова: середньогір'я, спеціальна підготовленість, гострота зору, вади зору.

\section{Вступ}

Тренування в умовах середньогір'я вже давно $€$ ефективним засобом підготовки кваліфікованих спортсменів до змагань високого рівню $[8,11]$.

Загальновизнано, що в умовах середньогір'я існує ряд факторів, що викликають гіпоксію в організмі людини. Головними з них є: щільність атмосферного тиску, зниження атмосферного та парціального тиску [2, 4]. Більшість науковців вважають, що саме гіпоксія є одним з факторів успішної підготовки до змагань та ефективним засобом мобілізації функціональних резервів організму і переведення його на новий, більш високий рівень адаптації для участі у змаганнях в умовах рівнини $[6,8,9$, 11]. Дж. Колба вважає, що тренування в гірських умовах сприяють економізації роботи, що виражається у збільшенні кисневої ємності крові та дифузії кисню в м'язову тканину [3]. B. Н. Тутевич, D. B. Dill, L. G. C. E. Pugh у своїх роботахвідмічають, що при пересуваннях в циклічнихвидах спорту в умовах розрідженої атмосфери можливий розвиток більш високих швидкостей, особливо окремих їі компонентів: частоти рухів та швидкості одиночного м'язового скорочення [17]. Вплив гіпоксії, обумовленої зниженням парціального тиску кисню у вдихуваному повітрі та гіпоксії, що виникає під впливом навантажень підвищеної інтенсивності на підготовленість спортсменів присвячені роботи А. З. Колчинської, В. М. Платонова, М. . Булатової [2, 4]. У роботах J. Vigil, Ф. П. Суслов, Є. Б. Гіппенрейтер, Т. В. Самоленко та В.М.Платонова наводяться зразкові моделі мезоциклів тренування висококваліфікованих спортсменів у середньогір'ї та високогір'ї під час підготовки до головних змагань року $[6,8,9,10$, $13,14]$. На думку Я. М. Коца [6], підвищення чутливості сенсорних апаратів під впливом комплексу кліматичних факторів середньогір'я веде до зменшення швидкості рухової реакції: латентного часу скорочення та розслаблення м`язів. В. М. Платонов вказує, що тренування в умовах середньогір'я, поряд з удосконаленням можливостей різних ланок системи енергозабезпечення, може негативно вплинути на найважливіші складові технічної та тактичної майстерності, а також ряд важливих компонентів фізичної та психічної підготовленості [9]. В той же час, А. З. Колчинська у своїх дослідженнях з`ясувала, що тренування в умовах середньогір'я за допомогою традиційних засобів та методів значно удосконалює витривалість та швидкісно-силові якості легкоатлетів-бігунів, ніж застосування цих же засобів в умовах рівнини [4].

У науковій та науково-методичній літературі широко описано застосування тренувань в умовах середньогір'я у багатьох видах спорту, особливо тих, що пов язані 3 проявом витривалості. Значно менше праць присвячено підготовці спортсменів у гірських умовах, у спортивній діяльності яких витривалість не є визначальним чинником (силові, швидкісно-силові, складно координаційні, єдиноборства). Застосування тренувань в умовах середньогір'я в підготовці спортсменів-паралімпійців з порушеннями зору на сьогодні не має наукового обґрунтування. Відсутні відомості і про вплив навантажень в умовах середньогір'я на функціональний стан зорового аналізатора. Тренери національної паралімпійської збірної України в підготовці спортсменів використовують «гірську» підготовку, покладаючись на свій власний досвід та досвід підготовки спортсменів, що не мають відхилень у стані здоров'я. Тому вивчення та з'ясування впливу тренувань в умовах середньогір'я на гостроту зору та рівень спеціальної підготовленості висококваліфікованих спринтерів з порушеннями зору є актуальним. 


\section{СЛОБОЖАНСЬКИЙ НАУКОВО-СПОРТИВНИЙ ВІСНИК}

Мета дослідження - визначити вплив тренувань в умовах середньогір'я на гостроту зору та рівень спеціальної підготовленості висококваліфікованих легкоатлетів з порушеннями зору, які спеціалізуються у спринтерському бігу.

Дослідження проводилось за темою «Особливості часово-просторових характеристик спортивної (легка атлетика) та повсякденної рухової діяльності» на 20202021 рр. (номер державної реєстрації 0119U103785).

\section{Матеріал і методи дослідження}

Дослідження проводилося у липні-серпні 2021 року під час підготовки спортсменів до XVI Паралімпійських ігор, що проводились у м. Токіо (Японія). У дослідженні брала участь Заслужений майстер спорту України з легкої атлетики серед спортсменів з порушеннями зору, Паралімпійська чемпіонка, рекордсменка світу. Дослідження проводилось у м. Кайсері (Туреччина) в умовах середньогір'я та відповідало біоетичним нормам. Спортсменка у складі національної паралімпійської збірної України з легкої атлетики проживала на висоті 1059 м над рівнем моря.

Під час тестування спортсменка виконувала кожну вправу по три рази. Усі результати відповідали модельним показникам для слабозорих спринтерів. Спортсменка, яка брала участь у дослідженні, була у віці 27 років та мала вроджене ушкодження зорового апарату: часткова атрофія зорового нерву обох очей. Відсоток ушкодження лівого ока вищий, ніж правого. Визначення гостроти зору досліджуваної спортсменки проводилося лікарем національної паралімпійської команди України з легкої атлетики за таблицею Сівцева. Оскільки зір спортсменки не дозволяв бачити символи таблиці з 5 м, для обліку використовували формулу Снеллена:

VISUS $=d / D$,

де $\mathrm{V}$ - візус,

d - відстань, з якої спортсменка бачила символ таблиці,
D - табличне значення, що вказується зліва в таблиці Сівцева.

Візометрія проводилася під час кожного тестування по три рази, відпочинок спортсменки між вимірюваннями складав 10-12 хвилин у положенні сидячи з закритими очима Показники гостроти зору легкоатлетки за міжнародною класифікацією відповідали класу Т13.

У дослідженні були використані наступні методи: аналіз і узагальнення науково-методичної літератури, аналіз документальних матеріалів (щоденники та плани підготовки), педагогічне спостереження, педагогічний експеримент (авто експеримент), візометрія, методи математичної статистики.

Статистичний аналіз отриманих даних був проведений на персональному комп'ютері з використанням Statgraphics Centurion 18 (версія 18.1.11), використовували t-test достовірності відмінностей середніх пов'язаних (залежних) вибірок.

\section{Результати дослідження}

Великий практичний досвід науковців і тренерів дозволяє стверджувати, що тренування в умовах середньогір'я досить ефективне для спортсменів, що спеціалізуються в різних видах спорту, в тому числі і таких, що вимагають прояву швидкісно-силових здібностей $[13,15,16,19] .3$ метою підготовки до кульмінаційних змагань року було складено навчально-тренувальний план та визначено вихідні показники гостроти зору й рівня підготовленості спортсменки, що брала участь у дослідженні (табл. 1-2).

Дані тестування на початку дослідження відповідали модельним характеристикам для слабозорих спринтерів високої кваліфікації.

Показники гостроти зору лівого ока на початку дослідження нижче, ніж правого. За міжнародною класифікацією показники гостроти зору досліджуваної легкоатлетки відповідали класу Т13.

Таблиця 1

Показники рівня підготовленості спортсменки на початку дослідження (n=1)

\begin{tabular}{|c|c|c|}
\hline \multirow[t]{2}{*}{ Показники } & \multicolumn{2}{|c|}{ Результат } \\
\hline & $\bar{X}$ & $\bar{\sigma}$ \\
\hline Стрибок у довжину з місця (м) & 2.60 & 0.03 \\
\hline Потрійний стрибок 3 місця (м) & 7.31 & 0.03 \\
\hline $\begin{array}{c}\text { Біг } 10 \text { м низького старту за } \\
\text { командою (c) }\end{array}$ & 1.62 & 0.03 \\
\hline Біг 30 м (c) & 4.01 & 0.04 \\
\hline Біг 100 м (c) & 12.65 & 0.05 \\
\hline Біг 150 м (c) & 19.78 & 0.03 \\
\hline
\end{tabular}

Таблиця 2

Показники гостроти зору на початку дослідження (n=1)

\begin{tabular}{|c|c|c|}
\hline Гострота зору (V) & \multicolumn{2}{|c|}{ Результат } \\
\cline { 2 - 3 } & $\bar{X}$ & $\sigma$ \\
\hline Праве око & 0.063 & 0.003 \\
\hline Ліве око & 0.065 & 0.001 \\
\hline
\end{tabular}


Таблиця 3

Показники рівня підготовленості наприкінці дослідження в умовах середньогір'я $(\mathrm{n}=1)$

\begin{tabular}{|c|c|c|c|c|c|c|c|c|}
\hline \multirow{2}{*}{ Показники } & \multicolumn{3}{|c|}{ На початку } & \multicolumn{3}{c|}{ Наприкінці } & \multirow{2}{*}{$\mathrm{t}$} & \multirow{2}{*}{ Р } \\
\cline { 2 - 7 } & $\bar{X}$ & $\mathrm{~m}$ & $\sigma$ & $\bar{X}$ & $\mathrm{~m}$ & $\sigma$ & & \\
\hline $\begin{array}{c}\text { Стрибок у довжину } \\
\text { 3 місця (м) }\end{array}$ & 2.60 & 0.02 & 0.03 & 2.66 & 0.02 & 0.03 & 17.00 & $<0.01$ \\
\hline $\begin{array}{c}\text { Потрійний стрибок } \\
\text { 3 місця (м) }\end{array}$ & 7.31 & 0.02 & 0.03 & 7.35 & 0.01 & 0.02 & 2.08 & $>0,05$ \\
\hline $\begin{array}{c}\text { Біг 10 м з низького } \\
\text { старту за командою } \\
\text { (с) }\end{array}$ & 1.62 & 0.02 & 0.03 & 1.56 & 0.02 & 0.03 & 19.00 & $<0.01$ \\
\hline Біг 30 м (с) & 4.01 & 0.03 & 0.04 & 3.91 & 0.02 & 0.03 & 17.32 & $<0.01$ \\
\hline Біг 100 м (с) & 12.65 & 0.04 & 0.05 & 12.23 & 0.05 & 0.08 & 6.93 & $<0.01$ \\
\hline Біг 150 м (с) & 19.78 & 0.02 & 0.03 & 19.28 & 0.13 & 0.19 & 4.80 & $<0,05$ \\
\hline
\end{tabular}

В перші 3 дні навчально-тренувального збору тренування були спрямовані на адаптацію спортсменки до фізичних навантажень в умовах середньогір'я. Спортсменка тренувалась 2 рази на день. Ранкові тренування складались з розминки, спеціальних вправ на відпрацювання техніки бігу, вправ на увагу, пробігання 4-5 відрізків та заминки. Вечірні тренування носили переважно силовий характер. Під час виконання фізичних навантажень у спортсменки спостерігалась задишка, легке запаморочення, показники чСС після виконання вправ становили 186-192 уд/хв., але через 1,5-2 хв. відпочинку вони знижувались до 120126 уд/хв. На нашу думку, це є реакцією спортсменки на природню гіпоксією, що є головною ознакою умов сердньогір'я.

Після адаптації до умов середньогір'я тренувальний тиждень спортсменки складався 3 5-ти тренувань на стадіоні (Ataturk Sport Hall, що розташований на висоті 1079 м над рівнем моря), 3-х тренувань у тренажерному залі, 3-х тренувань у басейні, 2-х кросів у горах на висоті 1200 м та 1 сходження у гори на висоту 1750 м над рівнем моря.

Спортсменка відмічала, що після кросу на висоті 1200 м над рівнем моря, вона відчувала приплив енергії, що відзначалося в легкості і швидкості бігу на стадіоні. Відбулася адаптація до гірських умов, що відобразилося у зникненні задишки, запаморочення; в очах спостерігалося ніби більше світла та яскравості. За день до повторного тестування рівня підготовленості, відбулося сходження групи на висоту 1750 м.
Наприкінці навчально-тренувального збору в умовах середньогір'я в усіх досліджуваних показниках, окрім потрійного стрибка з місця, спостерігалися статистично значущі відмінності (табл. 3).

Найбільший приріст спостерігався в результатах 3 бігу 10 м з низького старту за командою - 3,7\% та з бігу $100 \mathrm{M}-3,3 \%$. Результати спортсменки у стрибках з місця

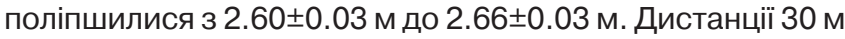
та 150 м спортсменка подолала швидше, ніж на початку на 2,49\% та 2,52\% відповідно. В потрійному стрибку з місця статистично значущих відмінностей між результатами на початку та наприкінці навчально-тренувального збору не спостерігалося $(p>0,05)$. Незначний приріст результатів у потрійному стрибку з місця пояснюється відносно коротким часом між проведенням тестувань, а також мимовільним страхуванням спортсменкою правої стопи після травми напередодні НТЗ в умовах середньогір'я.

Під впливом навантажень в умовах середньогір'я у спортсменки покращилась гострота зору (табл. 4) правого ока на 7,9\%, лівого - на 3,07\%. Відмінність приросту гостроти зору правого та лівого очей, на нашу думку, пов'язана з особливостями вродженого ушкодження зорового аналізатору досліджуваної спортсменки.

Після спуску з гір тижневий мікроцикл проводився за відновно-підтримуючим принципом, при значному зниженні загального об'єму та інтенсивності навантажень. Термін перебування в умовах середньогір'я базувався на рекомендаціях фахівців $[2,6,8,10]$ для спортсменів, які спеціалізуються в швидкісно-силових видах спорту та дорівнював двом тижням.

Таблиця 4

Показники гостроти зору наприкінці дослідження в умовах середьогір'я (n=1)

\begin{tabular}{|l|l|l|l|l|l|l|l|c|}
\hline \multirow{2}{*}{ Гострота зору (V) } & \multicolumn{3}{|c|}{$\begin{array}{c}\text { На початку } \\
\text { дослідження }\end{array}$} & \multicolumn{3}{c|}{$\begin{array}{c}\text { Наприкінці } \\
\text { дослідження }\end{array}$} & \multirow{2}{*}{$\mathrm{t}$} & \multirow{2}{*}{$\mathrm{p}$} \\
\cline { 2 - 9 } & $\bar{X}$ & $\mathrm{~m}$ & $\sigma$ & $\bar{X}$ & $\mathrm{M}$ & $\sigma$ & & \\
\hline Праве око & 0.063 & 0.02 & 0.03 & 0.068 & 0.02 & 0.033 & 14.00 & $<0.01$ \\
\hline Ліве око & 0.065 & 0.001 & 0.001 & 0.067 & 0.004 & 0.006 & 0.67 & $>0,05$ \\
\hline
\end{tabular}


Таблиця 5

Показники рівня підготовленості після спуску з гір (n=1)

\begin{tabular}{|c|c|c|c|c|c|c|c|c|}
\hline \multirow{2}{*}{ Показники } & \multicolumn{3}{|c|}{ Наприкінці збору в } & \multicolumn{3}{|c|}{ Через 10 днів після } & \multirow{2}{*}{$\mathrm{t}$} & \multirow{2}{*}{ Рмовах середньогір'я } \\
\cline { 2 - 7 } & $\bar{X}$ & $\mathrm{~m}$ & $\sigma$ & $\bar{X}$ & $\mathrm{~m}$ & $\sigma$ & & \\
\hline $\begin{array}{c}\text { Стрибок у } \\
\text { довжину 3 } \\
\text { місця (м) }\end{array}$ & 2.66 & 0.02 & 0.03 & 2.68 & 0.02 & 0.03 & 5.00 & $<0.01$ \\
\hline $\begin{array}{c}\text { Потрійний } \\
\text { стрибок 3 } \\
\text { місця (м) }\end{array}$ & 7.35 & 0.01 & 0.02 & 7.40 & 0.04 & 0.05 & 1.99 & $>0,05$ \\
\hline $\begin{array}{c}\text { Біг 10 м 3 } \\
\text { низького } \\
\text { старту за } \\
\text { командою (с) }\end{array}$ & 1.56 & 0.02 & 0.03 & 1.55 & 0.02 & 0.03 & 2.00 & $>0,05$ \\
\hline Біг 30 м (с) & 3.91 & 0.02 & 0.03 & 3.90 & 0.01 & 0.02 & 2.00 & $>0,05$ \\
\hline Біг 100 м (с) & 12.23 & 0.05 & 0.08 & 12.04 & 0.05 & 0.07 & 29.00 & $<0.01$ \\
\hline Біг 150 м (с) & 19.28 & 0.13 & 0.19 & 19.07 & 0.08 & 0.12 & 3.67 & $>0,05$ \\
\hline
\end{tabular}

Таблиця 6

Показники гостроти зору після спуску з гір (n=1)

\begin{tabular}{|c|c|c|c|c|c|c|c|c|}
\hline \multirow[t]{2}{*}{ Гострота зору (V) } & \multicolumn{3}{|c|}{$\begin{array}{l}\text { Наприкінці } \\
\text { дослілження }\end{array}$} & \multicolumn{3}{|c|}{$\begin{array}{c}\text { Через } 10 \text { днів після } \\
\text { спуску з гір }\end{array}$} & \multirow[t]{2}{*}{$\mathrm{t}$} & \multirow{2}{*}{$\mathrm{p}$} \\
\hline & $\bar{X}$ & $\mathrm{~m}$ & $\bar{\sigma}$ & $\bar{X}$ & $\mathrm{M}$ & $\sigma$ & & \\
\hline Праве око & 0.068 & 0.02 & 0.033 & 0.073 & 0.002 & 0.003 & 16.00 & $<0.01$ \\
\hline Ліве око & 0.067 & 0.004 & 0.006 & 0.068 & 0.002 & 0.003 & 1.00 & $>0,05$ \\
\hline
\end{tabular}

3 метою виявлення відставленого тренувального ефекту «гірської підготовки» було проведено тестування спортсменки через 10 днів після спуску з гір в умовах рівнини (табл. 5-6).

Приріст досліджуваних показників виявив найбільший відставлений тренувальний ефект від навантажень в умовах середньогір'я на результати змагальної дистанції спортсменки - в бігу на 100 м він поліпшився на 1,6\% порівняно з попереднім тестуванням.

Показники гостроти зору правого ока покращилися на 7,4\%, лівого - залишились практично незмінними.

Отже, отримані результати свідчать про позитивний вплив тренувальних навантажень в умовах середньогір'я на гостроту зору та рівень спеціальної підготовленості досліджуваної спортсменки.

\section{Висновки / Дискусія}

Аналіз наукової та науково-методичної літератури показав, що тренування в умовах середньогір'я застосовуються в більшості видів спорту, що пов'язані, в основному, з проявом витривалості, однак наукових матеріалів про застосування цього методичного прийому в підготовці спортсменів-паралімпійців не виявлено.

У результаті дослідження було підтверджено думку М. М. Булатової, про побудову тренувального процесу в умовах середньогір`я. Виявлено, що в основі раціонального планування та використання тренувальних навантажень лежить планомірне проходження етапу початкової (гострої) адаптації досліджуваної спортсменки до умов середньогір`я. Зниження навантажень в перші 3 дні навчально-тренувального збору призвели до успішного проходження періоду гострої акліматизації у слабозорої легкоатлетки.

Розширені та доповнені відомості А. З. Колчинської, В. М. Платонова, щодо впливу гіпоксії на підготовленість спортсменів. Виявлено, що тренування в умовах природньої гіпоксії поліпшують гостроту зору та рівень підготовленості бігунів-спринтерів з порушеннями зору.

Аналіз результатів висококваліфікованої легкоатлетки-спринтерки з вадами зору, отриманих після застосування тренувальних навантажень в умовах середньогір'я, свідчить, що результати у стрибках у довжину з місця, бігу на 10 м з низького старту за командою, бігу на 30 м, 100 м та 150 м достовірно змінилися. Достовірні зміни спостерігалися лише в гостроті зору правого ока. Таким чином, застосування в підготовці висококваліфікованої спринтерки з вадами зору тренувань в умовах середньогір'я позитивно вплинуло на рівень спеціальної підготовленості та показники гостроти зору.

Достовірний приріст результатів на змагальній дис- 
танції після десятиденного перебування в умовах рівнини дає змогу говорити, що такі навантаження можна використовувати в змагальному періоді на етапі безпосередньої підготовки до основних змагань.
Перспективи подальших досліджень. Матеріали дослідження дозволять проаналізувати підготовку висококваліфікованих бігунів-спринтерів з вадами зору з огляду на організацію їх річної підготовки.

Конфлікт інтересів. Автори заявляють, що відсутній конфлікт інтересів, який може сприйматись таким, що може завдати шкоди неупередженості статті.

Джерела фінансування. Ця стаття не отримала фінансової підтримки від державної, громадської або комерційної організації.

\section{Список посилань}

1. Аджаметова Л., Шестерова Л. (2018), «Особливості фізичної підготовки бігунів-спринтерів з вадами зору на різних етапах багаторічного вдосконалення», Сучасні тенденції розвитку легкої атлетики: збірник наукових праць, Вип. 2. С, 53-57.

2. Булатова М. М. (1996), Теоретико-методические основы реализации функциональных резервов спортсменов в тренировочной и соревновательной деятельности : дис. на соискание науч. степени д-ра пед. наук. К., 356 с.

3. Колб Дж. (2003), Факторы окружающей среды. Спортивная медицина, Киев : Олимпийская література. C. $265-280$.

4. Колчинская А. 3. (1990), «О физиологических механизмах, определяющих тренирующий эффект средне- и высокогорья», Теория и практика физической культуры, № 4, С. 39-43.

5. Коскин С. А. (2007), «Современные объективные методы визометрии в целях врачебной экспертизы», Вестн. Росс. воен.-мед. акад., №4 (20), С 53-60.

6. Коц Я. М. (1998), Спортивная физиология: учебник для институтов физической культуры. Москва: Физкультура и спорт. 258 с.

7. Пасечникова Н. В. (2009), «Врожденная, наследственная и рано приобретенная патология глаз в формировании слепоты и слабовиденья в Украине», Вроджена та генетично обумовлена сліпота та слабкозорість. Проблеми діагностики, обстеження та комплексне лікування: IV науково-практична конференція дитячих офтальмологів України з міжнародною участю. Партеніт, Алушта, АР Крим, С. 316-322.

8. Платонов В. Н. (2013), Периодизация спортивной тренировки. Общая теория и ее практическое применение. К. : Олимп. лит., С. 486-514.

9. Платонов В. Н., Булатова М. М. (1995), Гипоксическая тренировка в спорте. Москва : Hypoxia medical, C. 17-23

10. Самоленко Т. В. (2012) «Использование тренировок в горных условиях в олимпийском годичном цикле подготовки в беге на средние дистанции», Физическое воспитание студентов, № 3, С. 103-107. $176 \mathrm{c}$.

11. Суслов Ф. П. (2000), Подготовка спортсменов в горных условиях. Москва: Терра-Спорт, Олимпия Пресс.

12. Ту Яньхао, Шестерова Л. Е. (2017), «Влияние тренировок в среднегорье и высокогорье на физическую подготовленность бегунов на средние дистанции, проживающих в различних климатических условиях», Науковий часопис Національного педагогічного університету імені М. П. Драгоманова, Вип. 8 (90), №17, С. 53-57.

13. Шестерова Л. Є. (2019), «Гіпоксичне тренування у підготовці бігунів, що спеціалізуються у видах витривалості», Основи побудови тренувального процесу в циклічних та екстремальних видах спорту: збірник наукових праць. Харків, Вип. 3, С. 91-98.

14. Шестерова Л., Пятницька Д. (2020) «Вплив тренувань у гірських умовах на підготовленість кваліфікованих бігунів на середні дистанції, що проживають на різних висотах», Основи побудови тренувального процесу в циклічних та екстремальних видах спорту: збірник наукових праць. Харків,.Вип. 4, С. 112-120

15. Шестерова Л. Е., Ту Яньхао (2015), «Динамика физической подготовленности бегунов на средние дистанции, проживающих в различных климатических условиях», Слобожанський науково-спортивний вісник, № 4, C. $100-104$.

16. Шестерова Л. Е., Ту Яньхао (2015), «Изменение уровня физической подготовленности квалифицированных бегунов на средние дистанции под влиянием тренировок в условиях среднегорья и высокогорья", Основи побудови тренувального процесу в циклічних видах спорту: зб. наукових праць I Всеукр. науково-практичної Інтернет-конференції (12-13 березня 2015 р.), Харків : ХДАФК, С. 85-88.

17. Dill D. В. (2005), "Comparative physiology in high altitudes», Journal of Cellular and Comparative Physiology, № 8 (3), pp. 301-313.

18. Hitzeman S. A., Beckerman S. A. (1993), «What the literature says about sports vision», Optom Clin, №3 (1), pp. 145-69.

19. Shesterova L. Ye., Efremenko A. N., Apaichev A. V., Samolenko T. V., Maslyak I. P., Tu Yanhao, Perevoznik V. I., Krainik Ya. B. (2018), "Change in the results of middle-distance runners living at different heights above sea level», Journal of Physical Education and Sport (JPES), 18 (Supplement issue 4), Art 280, pp. 1902 - 1906, 2018. DOI:10.7752/jpes.2018. s4280.

20. Vigil J. (1995), Road to the top. Great Britain: Creative Designes, 252 p.

21. Weber W. (1992), Mechanics of the human walking apparatus. Berlin: Springer-Verlag, $242 \mathrm{p}$.

22. Winter D. (1990), Biomechanics and motor control of Human movement. New York: John Wiley \& Sons, $277 \mathrm{p}$.

23. Wylegala A. (2016), «The effects of physical exercises on ocular physiology», J Glaucoma, №25 (10), pp. 843-849.

Стаття надійшла до редакції: 18.11.2021 р.

Опубліковано: 23.12.2021 p.

Аджаметова, Л. (2021), «Підготовка висококваліфікованих спринтерів з вадами зору в умовах середньогір'я»
Слобожанський науково-спортивний вісник, № 6(86), С. 64-70, doi:10.15391/snsv.2021-6.010 


\begin{abstract}
Аннотация. Лейля Аджаметова. Подготовка высококвалифицированных спринтеров с нарушением зрения в условиях среднегорья. Цель: определить влияние тренировок в условиях среднегорья на остроту зрения и уровень специальной подготовленности высококвалифицированных легкоатлетов с нарушением зрения, специализирующихся в спринтерском беге. Материал и методы: исследования проводилось с участием Заслуженного мастера спорта Украины по легкой атлетике среди спортсменов с нарушениями зрения в условиях среднегорья. В исследовании были использованы следующие методы: анализ и обобщение научно-методической литературы, анализ документальных материалов (дневники и планы подготовки), педагогическое наблюдение, педагогический эксперимент (автоэксперимент), визометрия, методы математической статистики. Результаты: тренировки в условиях среднегорья привели к положительным изменениям показателей остроты зрения и уровня специальной подготовленности спортсменки. Выводы: применение в подготовке высококвалифицированной спринтерши с нарушением зрения тренировок в условиях среднегорья положительно повлияло на уровень специальной подготовленности и на остроту зрения.
\end{abstract}

Ключевые слова: среднегорье, специальная подготовленность, острота зрения, нарушение зрения.

Abstract. Leilia Adzhametova. Middle mountains training of high-qualified visually impaired sprinters. Purpose: determine the impact of middle mountains training on the visual acuity and the level of preparadness of highly qualified visually impaired sprinters. Material and methods: we studied the indicators of the level of preparadness and visual acuity of the Honored Master of Sports of Ukraine in para-athletics among athletes with visual impairmants in the middle mountains. The following methods were used: analysis and generalization of scientific and methodological literature, analysis of training loads and processing of parameters of training activity, pedagogical observation, pedagogical experiment (auto experiment), visometry, methods of mathematical statistics. Results: middle mountains training led to positive changes in the indicators of the functional state of the visual analyzer and the level of preparadness of athlete. Conclusions: the use of preparation of highly qualified visually impaired sprinter in middle mountains training positively influenced the development of the level of special preparadness and the visual acuity.

Keywords: middle mountains, special preparadness, visual acuity, visually impaired.

\title{
References
}

1. Adzhametova, L., Shesterova, L. (2018), «Features of physical training of sprinters with visual impairments at different stages of long-term improvement», Suchasni tendentsiyi rozvytku lehkoyi atletyky: zbirnyk naukovykh prats, Vol. 2. pp. 53-57. (in Ukr).

2. Bulatova, M. M. (1996), Teoretiko-metodicheskiye osnovy realizatsii funktsionalnykh rezervov sportsmenov $v$ trenirovochnoy $i$ sorevnovatelnoy deyatelnosti [Theoretical and methodological foundations for the implementation of the functional reserves of athletes in training and competitive activities]: dys. na polucheniye nauch stepeni d-ra ped. nauk, K., 356 p. (in Russ.).

3. Kolb, Dzh. (2003), Faktory okruzhayushchey sredy. Sportivnaya meditsina, [Environmental Factors. Sports medicine], Kiev: Olimp. lit., pp. 265-280. (in Russ).

4. Kolchinskaya, A. Z. (1990), "On the physiological mechanisms that determine the training effect of medium and high mountains», Teoriya i praktika fizicheskoy kultury, №.4, pp. 39-43. (in Russ.).

5. Koskin, S. A. (2007), «Modern objective methods of visometry for the purpose of medical expertise», Vestnik Rossiyyskoy voyenno-meditsinskoy akademii, №4 (20), pp. 53-60. (in Russ.).

6. Kots, Ya. M. (1998), Sportivnaya fiziologiya [Sports physiology], uchebnik dlya institutov fizicheskoy kultury. M.: Izdatelstvo Fizkultura i sport, 258 p. (in Russ.).

7. Pasechnikova, N. V. (2009), «Congenital, hereditary and early acquired eye pathology in the formation of blindness and low vision in Ukraine», Vrodzhena ta henetychno obumovlena slipota ta slabkozorist. Problemy diahnostyky, obstezhennya ta kompleksne likuvannya: IV naukovo-praktychna konferentsiya dytyachykh oftalmolohiv Ukrayiny z mizhnarodnoyu uchastyu. Partenit, AR Krym, pp. 316-322. (in Russ.).

8. Platonov, V. N. (2013), Periodizatsiya sportivnoy trenirovki. Obschaya teoriya i ee prakticheskie prilozheniya [Periodization of sports training. General theory and its practical applications], Kiev: Olimp. lit., pp. 486-514. (in Russ.).

9. Platonov, V. N., Bulatova, M. M. (1995), Gipoksicheskaya trenirovka v sporte [Hypoxic training in sport]. M.: Hypoxia medical, pp. 17-23. (in Russ.).

10. Samolenko, T. V. (2012) «The use of training in mountain conditions in the Olympic annual cycle of training in running at average distances», Fizicheskoye vospitaniye studentov, № 3, pp. 103-107. (in Russ.)

11. Suslov, F. P. (2000), Podgotovka sportsmenov v gornykh usloviyakh [Training of athletes in mountain conditions]. M.: TerraSport, Olimpiya Press, 176 p. (in Russ.).

12. Tu, Yanhao, Shesterova, L. Ye. (2017), "The influence of training in the middle and high mountains on the physical fitness of middle-distance runners living in different climatic conditions", Naukoviy chasopis Natshonalnogo pedagoghchnogo unHversitetu нmenн M. P. Dragomanova, Vol. 8 (90), №17, pp 53-57. (in Russ.).

13. Shesterova, L. E. (2019), «Hypoxic training in the training of runners specializing in endurance», Osnovy pobudovy trenuvalnoho protsesu v tsyklichnykh ta ekstremalnykh vydakh sportu: zbirnyk naukovykh prats, Kharkiv. Vol. 3, pp. 91-98. (in Russ.).

14. Shesterova, L., Pyatnytska, D. (2020), «The impact of training in mountain conditions on the training of skilled middle distance runners living at different altitudes», Osnovy pobudovy trenuvalnoho protsesu v tsyklichnykh ta ekstremalnykh vydakh sportu: zbirnyk naukovykh prats. Kharkiv, Vol. 4, pp. 112-120. (in Ukr)

15. Shesterova, L. Ye., Tu, Yanhao (2015), «Dynamics of physical fitness of middle-distance runners living in different climatic conditions», Slobozhanskiy naukovo-sportivniy visnik, № 4, pp. 100-104. (in Russ.).

16. Shesterova, L. Ye., Tu, Yanhao (2015), "Changing the level of physical fitness of skilled runners in medium distances under the influence of training in the highlands and highlands», Osnovy pobudovy trenuvalnoho protsesu v tsyklichnykh vydakh sportu: zbirnuk. naukovykh prats I Vseukr. naukovo-praktychnoyi Internet-konferentsiyi (12-13 bereznya 2015). Kharkiv: KHDAFK, pp. 85-88. (in Russ.).

17. Dill, D. B. (2005), «Comparative physiology in high altitudes», Journal of Cellular and Comparative Physiology, № 8 (3), pp. 301-313. (in Eng.).

18. Hitzeman, S. A., Beckerman, S. A. (1993), «What the literature says about sports vision», Optom Clin, №3 (1), pp. 145-69. (in Eng.).

Аджаметова, Л. (2021), «Підготовка висококваліфікованих спринтерів з вадами зору в умовах середньогір'я»
Слобожанський науково-спортивний вісник, № 6(86), С. 64-70, doi:10.15391/snsv.2021-6.010 
19. Shesterova, L. Ye., Efremenko, A. N., Apaichev, A. V., Samolenko, T. V., Maslyak, I. P., Tu, Yanhao, Perevoznik, V. I., Krainik, Ya. B. (2018), "Change in the results of middle-distance runners living at different heights above sea level», Journal of Physical Education and Sport, 18 (Supplement issue 4), Art 280, pp. 1902 - 1906, 2018. DOI:10.7752/jpes.2018.s4280. (in Eng.).

20. Vigil, J. (1995), Road to the top. Great Britain: Creative Designes, 252 p. (in Eng.).

21. Weber, W. (1992), Mechanics of the human walking apparatus. Berlin: Springer-Verlag, 242 p. (in Eng.).

22. Winter, D. (1990), Biomechanics and motor control of Human movement. New York: John Wiley \& Sons, 277 p. (in Eng.).

23. Wylegala, A. (2016), «The effects of physical exercises on ocular physiology», J Glaucoma, №25 (10), pp. 843-849. (in Eng.).

Received: 18.11.2021.

Published: 23.12.2021.

Відомості про авторів / Information about the Authors

Аджаметова Лейля Ільясівна: аспірантка; Харківська державна академія фізичної культури: вул. Клочківська 99, м. Харків, 61058, Україна.

Аджаметова Лейля Ильясовна: аспирантка; Харьковская государственная академия физической культуры: ул. Клочковская 99, г. Харьков, 61058, Украина.

Leilia Adzhametova: postgraduate; Kharkiv State Academy of Physical Culture: Klochkivska 99, Kharkiv, 61058, Ukraine.

ORCID: https://orcid.org/0000-0001-6673-3686

E-mail: Leilia090394@gmail.com 